\title{
Lived experiences of male intimate partners of female rape victims in Cape Town, South Africa
}

\begin{tabular}{|c|c|}
\hline \multicolumn{2}{|c|}{$\begin{array}{l}\text { Authors: } \\
\text { Evalina van Wijk }{ }^{1} \\
\text { Sinegugu E. Duma }{ }^{2} \\
\text { Pat M. Mayers }{ }^{2}\end{array}$} \\
\hline \multicolumn{2}{|c|}{$\begin{array}{l}\text { Affiliations: } \\
{ }^{1} \text { Western Cape College of } \\
\text { Nursing in association with } \\
\text { University of Cape Town, } \\
\text { South Africa }\end{array}$} \\
\hline \multicolumn{2}{|c|}{$\begin{array}{l}{ }^{2} \text { Division of Nursing and } \\
\text { Midwifery, Faculty of Health } \\
\text { Sciences, University of } \\
\text { Cape Town, South Africa }\end{array}$} \\
\hline \multicolumn{2}{|c|}{$\begin{array}{l}\text { Correspondence to: } \\
\text { Pat Mayers }\end{array}$} \\
\hline \multicolumn{2}{|c|}{$\begin{array}{l}\text { Email: } \\
\text { pat.mayers@uct.ac.za }\end{array}$} \\
\hline \multicolumn{2}{|c|}{$\begin{array}{l}\text { Postal address: } \\
\text { Faculty of Health Sciences, } \\
\text { University of Cape Town, } \\
\text { Observatory 7925, } \\
\text { South Africa }\end{array}$} \\
\hline \multicolumn{2}{|c|}{$\begin{array}{l}\text { Dates: } \\
\text { Received: } 28 \text { June } 2013 \\
\text { Accepted: } 22 \text { May } 2014 \\
\text { Published: } 23 \text { Sept. } 2014\end{array}$} \\
\hline \multicolumn{2}{|c|}{$\begin{array}{l}\text { How to cite this article: } \\
\text { Van Wijk, E., Duma S.E. } \\
\text { \& Mayers, P.M., 2014, } \\
\text { 'Lived experiences of male } \\
\text { intimate partners of female } \\
\text { rape victims in Cape Town, } \\
\text { South Africa', Curationis } \\
\text { 37(1), Art. \#1199, } 9 \text { pages. } \\
\text { http://dx.doi.org/10.4102/ } \\
\text { curationis.v37i1.1199 }\end{array}$} \\
\hline \multicolumn{2}{|c|}{$\begin{array}{l}\text { Copyright: } \\
\text { (C) 2014. The Authors. } \\
\text { Licensee: AOSIS } \\
\text { OpenJournals. This work } \\
\text { is licensed under the } \\
\text { Creative Commons } \\
\text { Attribution License. }\end{array}$} \\
\hline \multirow{2}{*}{ 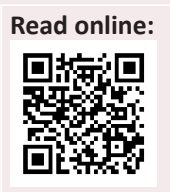 } & \\
\hline & $\begin{array}{l}\text { Scan this QR } \\
\text { code with your } \\
\text { smart phone or } \\
\text { mobile device } \\
\text { to read online. }\end{array}$ \\
\hline
\end{tabular}

Background: Sexual violence in South Africa is a major public health and social problem. Sexual assault or rape is a traumatic event which disrupts not only the life of the female rape victim, but also that of her male intimate partner (MIP), irrespective of whether he witnessed or was informed of the incident.

Objectives: The study aimed to explore the lived experiences of MIPs of female rape victims and the meaning of these experiences in the six months following the partner's rape.

Method:We conducted a longitudinal hermeneutic phenomenological study. Nine purposively sampled adult MIPs were interviewed over a period of six months. The participants were in an intimate relationship with a female rape victim prior to and immediately after the rape; their partners had been treated at a specialised centre for victims of rape and sexual assault. Four interviews were conducted with each of the nine intimate partners of female rape victims: (1) within 14 days of, (2) a month after, (3) three months after, and (4) six months after the rape.

Results: Two major themes emerged: being-in-the-world as a secondary victim of rape, and living in multiple worlds, those of their female partners, family, friends, society, employers or colleagues, professionals and the justice system. The participant's familiar world became strange and even threatening, and his relationship with his partner became uncertain.

Conclusion: Early supportive intervention for intimate partners of female rape victims is required to prevent on-going emotional trauma and alleviate the effects of chronic posttraumatic stress disorder and suffering at intra- and interpersonal levels.

\section{Introduction}

Sexual violence in South Africa is a major public health and social problem (Meel 2005; Dartnall \& Jewkes 2013). A total of 68332 cases were reported to the South African Police Service during the period 2009 and 2010, with a reported rape crime ratio of 100 per 100000 members of the population (South African Police Service 2012). Most rapes occur at the victims' homes, and in $90 \%$ of cases the victims know their offenders (Meel 2005 ). Current South African statistics are inaccurate due to under-reporting and do not reflect the extent of sexual assault on women (Jacobson 2009). Although rape is reported in both females and males, females are at substantially higher risk of assault (Campbell \& Wasco 2005).

Rape affects the victim and those close to her, especially the intimate partner. Sexual assault is a traumatic and devastating event which not only disrupts the life of the female rape victim, but also the life of her male intimate partner (MIP), irrespective of whether he witnessed or was informed of the incident (O'Sullivan 2003; Remer 2001; Van den Berg \& Pretorius 1999; Christiansen, Bak \& Elklit 2012). Women need the support of those who play an important role in their lives (Duma, Mekwa \& Denny 2007a). The male partner, although also affected by the assault on his partner, is often the one who is expected to support his partner and meet her needs. Seldom is the MIP of a female rape victim assessed for psychological problems and difficulties he may experience as a result of the trauma (Smith 2005).

A South African study which investigated the impact of stranger rape on the significant other from the account of the primary victim, reported that both the rape victim and her intimate partner displayed cognitive, behavioural and affective reactions attributable to the rape incident (Van den Berg \& Pretorius 1999). Other studies have documented the effects of rape on the rape victim's significant others, including intimate partners, friends and family members (Morrison, Quadara \& Boyd 2007; Remer \& Ferguson 1995; Christiansen et al. 2012).

Haansbaek (2006) identified the psychological reactions of intimate partners of women who had been sexually assaulted and the consequences thereof on the sexual relationship; these included fear, guilt, anger and difficulty in focusing on daily life after the rape and disturbance 
in sexual relationships for some time after the rape incident. Interactions between rape victims and their families and friends during the adjustment phase of recovery from rape victim to survivor are often disrupted, with evidence of social withdrawal and isolation (Miller, Williams \& Bernstein 1982). The role played by the intimate partners in enhancing the recovery process of rape victims has been documented in a number of studies (Ahrens \& Campbell 2000; Campbell \& Wasco 2005; Daane 2005; Duma, Mekwa \& Denny 2007b).

\section{Problem statement}

There is limited support in South Africa for the intimate partners and significant others after the rape of their partners, even though there is some evidence that such care can make a difference in their lives (Duma et al. 2007a; 2007b; Rudd 2003; Van den Berg \& Pretorius 1999). In South Africa there is a perceived lack of adequate interventions and support programmes for the intimate partners of victims of rape and its consequences. Lack of professional support for the secondary victim impairs that individual's daily occupational and social functioning, which can result in absenteeism, fatigue, impaired communication, poor concentration and relationship dysfunction (Schiraldi 2000). It was against this background that the study was conducted.

\section{Aims of the study}

The aim of the study was to explore, analyse and interpret the lived experiences of MIPs of female rape victims and the meaning of these experiences in the six months following the partner's rape.

\section{Research method and design}

A longitudinal hermeneutic phenomenological study was conducted, in which MIPs were interviewed over a period of six months. This approach has its focus on interpretation of language and meanings of individuals' experiences (Lindseth \& Norberg 2004; Creswell 2007). The six months following the rape of a female intimate partner was selected as a reasonable period within which to explore the lived experience of her MIP (Molloy, Woodfield \& Bacon 2002).

\section{Study setting}

A specialised centre for comprehensive treatment and support of victims of rape and sexual assault situated in a public hospital in a low socio-economic area of Cape Town was the study setting for recruitment of the intimate partners. The centre provides services for persons from the surrounding area, which comprises formal and informal housing settlements.

\section{Study population and sampling}

All MIPs of female rape victims who received treatment for rape at the selected centre in Cape Town, South Africa, during the study period were considered for inclusion in the study. The participants were purposefully sampled and recruited into the study if they were in an intimate relationship with a female rape victim before and immediately after the rape event (as revealed by the rape victim to nursing staff), were older than 18 years, able to communicate in one of the three main languages spoken in the region (isiXhosa, English or Afrikaans), and voluntarily contacted the researcher telephonically within 14 days of learning of the study to indicate their willingness and availability to participate in the study for a period of six months. Partners of male rape victims were excluded from the study due to the relative infrequency of male rape. Data collection was stopped when repetition of the data obtained from nine MIPs occurred.

\section{Gaining access}

Due to the sensitive nature of the study, mediated access was arranged through provision of information to staff of the centre, once ethical approval had been obtained. Women who attended the centre for post-rape treatment and management were invited to inform their partners about the study. They were provided with printed research information and the researcher's contact details to discuss with their intimate partners. Potential participants were asked to contact the researcher voluntarily within 14 days of the incident. After contact was initiated, the researcher met potential participants. The nature of the study and the requirements of participation were explained; thereafter, if the person agreed to take part written information about the study was given and written informed consent obtained.

\section{Participants}

All nine cases of rape had been reported to the police. The ages of the MIPs ranged from 25 to 54 years. All of the participants lived in low-income housing or informal settlements within the geographical area of the study site. Eight participants were employed and lived with their female partners. Six of the participants were South African and the others were either economic migrants or refugees from Central Africa. Persons unknown to the victims or MIP participants had committed the crime in all but one instance; in this case the MIP's wife had been raped by a neighbour.

\section{Data collection method}

Data were collected over a 12-month period between August 2008 and August 2009. Two participants who met the criteria for inclusion in the study participated in a pilot study. Based on these interviews, the interview questions were modified slightly to ensure that their meaning was understood in each of the three local languages (Kim 2011). This approach facilitates contextual sensitivity and is particularly important when the nuances of language need to be explored. The pilot study participants chose to be interviewed in English; however, they recommended that the services of an interpreter be available for subsequent interviews. Because the the researcher was fluent in only English and Afrikaans, an IsiXhosa-speaking interpreter was employed to facilitate recruitment and data collection. Data from all interviews were included in the final data analysis. 
Four face-to-face, in-depth interviews were conducted with each participant over a six-month period. There was a specific focus in each interview, as detailed in Table 1. The longitudinal approach facilitated exploration and understanding of the participants' lived experiences over time.

Probes, active listening and reflective comments encouraged the participants to elaborate on their feelings, as well as on positive and negative experiences in the time following the rape of their intimate partners. All interviews were conducted in English, with the assistance of an iSiXhosa-speaking interpreter for the Xhosa participants. The duration of each interview was between one and two hours and they were digitally recorded. At the end of each interview session the researcher summarised the key emerging issues. Throughout the study regular telephonic contact was kept with the participants to maintain continued interest in participating.

Sections of the interviews in which participants spoke in IsiXhosa were immediately translated into English as part of the audio recordings. The verbatim transcriptions were checked and back-checked for accuracy by two qualified translators. Preliminary data analysis of an interview transcript was done prior to the next interview with each participant, in order to provide the foundation for the next interview.

\section{Data analysis}

The data analysis methods of Colaizzi (1978) and the within-case and across-case approach (Ayres, Kavanaugh \& Knafl 2003) were used to analyse and interpret the transcribed data. Data analysis was guided by the interpretive theory of Paul Ricœur (1976). For Ricœur (1983) the object of interpretation is to produce an emotional relationship with the text that then generates a new interpretation. The interpretation of the data involved reflecting on the initial reading thereof with an interpretive lens to ensure comprehensive understanding of the findings.

\section{Results}

Two major themes emerged: being-in-the-world as a secondary victim of rape, and living in multiple worlds the worlds of their female partners, family, friends, society, employers or colleagues, professionals and the justice system.

\section{Being-in-the-world as a secondary victim of rape}

Upon disclosure of the rape event, the participants were immediately forced to face the shocking reality of the violation of their partner. They were propelled into a world they never believed possible as secondary victims of rape. The rape of their partners immediately turned their own lives upside down, as described by this participant:

'When I returned home from work, I see the door was halfway closed ... I saw the one guy is on top of my pregnant girlfriend whilst the other one was busy undressing ... I can still remember my girlfriend looked so helpless whilst screaming at them to leave her alone ... both the guys appeared drunk ... when I see this, I felt so powerless ... I couldn't move so shocked I was ... I couldn't believe they did this to my girlfriend; it is so mean.' (Participant 5)

Frustration and feelings of powerlessness were overwhelming, as described by this participant:

'I started shouting to get help, but nobody [starts crying] wanted to help me to look for her ... I was feeling so helpless but start searching myself ... when I found her, I could not believe what she told me; I was so frustrated and shocked; I couldn't believe it when she told me that she was raped whilst I was in the shop.' (Participant 2)

One month post-rape, the participants in the study reported that they felt humiliated and horrified about what had happened and had a sense of personal vulnerability:

'I felt very hurt because if you want to hurt a man, the only way is to sleep with his wife. So sleeping with my wife without my consent, raping her, it's very hard for one to accept in life, you see; so far, it has changed my life so much because right now I don't have that certainty to see - right now I don't have that manhood, that I am still a man, you see. I don't know how I can explain it, you see. It has changed me so much.' (Participant 4)

At the interview sessions four weeks after the rape, a number of participants expressed their horror at what had happened; not only to their partners but to their future. The rape of their partners was a defining moment in their lives, which would stay with them:

'I don't know how we will ever overcome this thing ... so it hurts, you know, it hurts ... So it's not something that I have to accept just easily.' (Participant 8 )

'The rape changed everything that we planned. We have been going out for seven years, and we have a nice relationship, and

TABLE 1: Interview schedule.

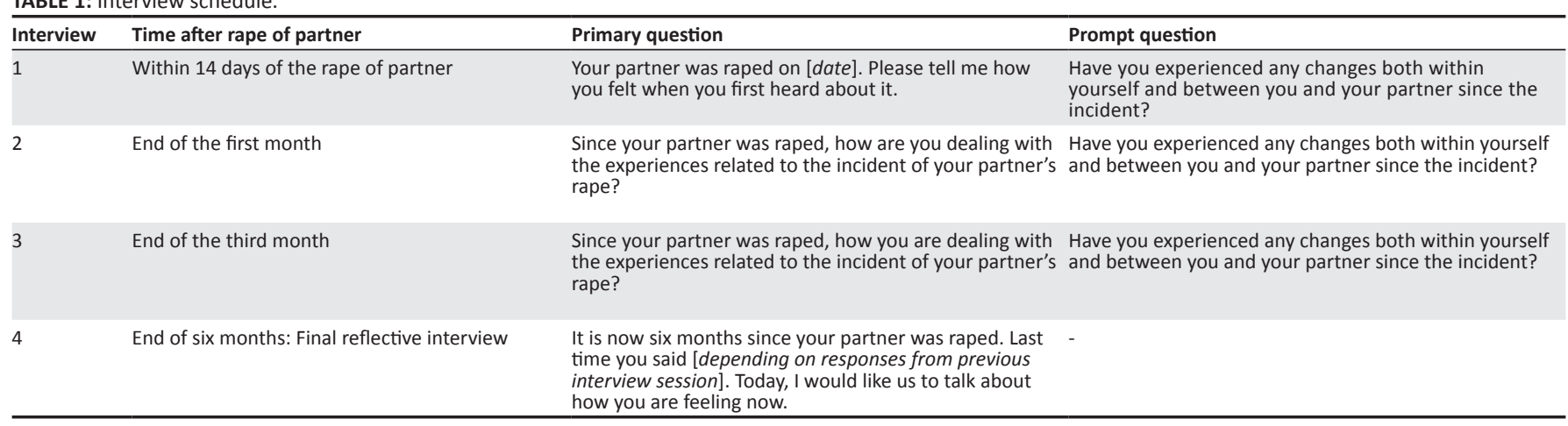


I am looking forward to make her my wife. So what those guys did, actually they put our relationship at risk.' (Participant 4)

Four weeks after the rape most of the participants had not changed their opinions and described in agitated voices how they were feeling about the injustice of the situation:

'Although it is a month ago, I'm still having that thing, I still have that anger. I don't know how long it will take for me to understand the situation, but I'm still very angry what the locals do to her.' (Participant 4)

\section{Violation of one's intimate property}

The distress at their partners' rape was compounded by the sense that their intimate property -expressed by participants as 'my possession', 'my intimate property' and 'my pride' (Participant s 1, 4, 8, 9), had been violated. The Xhosa intimate partners felt that no man had the right to take their property, for which they had paid lobola (a traditional Southern African custom whereby the man pays the family of his bride-to-be for her hand in marriage):

'The moment that man raped my wife, he took my pride which belongs to me ... you see, in our culture, we pay lobola for our wives, so she is mine, and he cannot do that to me.' (Participant 1)

\section{Guilt and helplessness}

The first three interviews were characterised by the MIPs' expressions of vacillation between feelings of intense guilt and feelings of helplessness for not being there to protect their partners. They felt that they had neglected their roles as men:

'I feel so guilty and blame myself that she was raped here in Cape Town ... If I did not put that much pressure on her, she would still be okay ... you know; I feel so bad and sorry for her that I was not there to save her out of his claws.' (Participant 2)

As secondary victims, the participants' worlds became intertwined with the lived world of their intimate partners, as not only the partners but they as MIPs had to engage with family, friends, society, employers or colleagues, professionals and the justice system.

\section{Being-in-the-world with their partners}

During the first three months post-rape, despite their uncertainty about their partner's feelings about sexual intimacy and their fear of contracting HIV, there was a desire to continue sexual relations. The couples who had been able to resume sexual relations had been more consistent in the use of condoms as protection. They expressed concern about sexually transmitted diseases, and it was important for them that their partners take their antiviral medication as prescribed:

'Since my wife was raped, both of us have a desire for sex, and although I used a condom, I just tell her, I am your husband - and we hug and kiss each other, and both of us enjoy it.' (Participant 3)

'We're still using protection ... because I know she is my partner, and she knew the same, we didn't use protection before, and although the blood results were negative, we rather want to be safe.' (Participant 6)

For this participant, fear and uncertainty meant that he had avoided sexual intimacy since the rape of his partner:

'The people talk about the disease, especially HIV and AIDS ... what now if my partner has been infected? You know, it's going to affect me for the rest of my life ... it's something that I have to think about ... so the thought of HIV really affects my sex life ... in fact, I have no sex life on the moment.' (Participant 8)

Communication about intimacy and sex were avoided for fear of evoking unpleasant feelings between them. At his third interview session, a participant remarked:

'You know, when you don't have a sexual appetite, penetration is always difficult ... does she not think that I also have needs? Her attitude discourages me to ask her for sex ... this is not a good sign for our marriage and future; it is very sad and disappointing to me. ... So things like that affect me ... I can say that it's important to have sex ... that's the expression of love, and now it's me asking for sex once per month ... I am so worried that if we are not having sex, it will separate you.' (Participant 8)

For another participant, the difficulty of broaching the topic of intimacy created a sense of loss and frustration:

'Although I feel sexually frustrated I do not feel comfortable to ask for sex ... because she is not the same person I knew... this is upsetting and breaks my heart.' (Participant 8)

It was difficult to discuss their feelings with their partners. Even their communication about everyday issues, such as their children, was limited:

'We hardly communicate with each other and I really miss those precious moments of the past when we were being able to share our thoughts with each other... if we start talking to each other now it always ends up in a mess ... then we will not talk to each other for days.' (Participant 9)

Despite attempts to re-establish meaningful communication with their partners, at the three- month post-rape interviews the participants expressed feelings of abandonment as a result of their partners' aloof and labile behaviour:

'Me and my wife can't talk about the rape without arguing about it $\ldots$ because when I start talking to her about how the rape affected both our lives and marriage, the one moment, she start to cry, the other moment, she is so agitated and accuses me that I don't care about how she is feeling and that I don't know what she is going through.' (Participant 4)

At their last interview session the participants reported that they believed that if integrated support services had been available, then this support would have helped them to gain better knowledge of the physical and mental health impact of rape on both of them. Also, they might have gained a better understanding of their relationship difficulties, as expressed by this participant:

'By the time I was sitting there and she was in the other room, I thought maybe there will be someone who's going to come and talk to me ... but unfortunately that never happened. ... I feel so 
angry and hurt that nobody at the police station cared about me; they were talking to my girlfriend in their office, and not one of them talked to me.' (Participant 2)

None of the participants had sought sexual satisfaction outside of their relationships, but only two reported having resumed normal sexual activity by the time of the final interview.

\section{Living in multiple worlds Being-in-the-world with others}

Being-in-the-world with others included family, friends and professionals, employers and colleagues. Support from employers, colleagues, family, friends and others facilitated the process of re-engaging with everyday lives and relationships, but this did not always occur. It was, however, difficult for the men who were employed to disclose the traumatic experience. Although eight of the MIPs were permanently employed, only three of them felt that they had an open relationship with their employer. An unintended therapeutic benefit of the study interviews enabled this participant to disclose:

'It is only you and my boss I trust ... my boss is now very supportive after I followed your advice to inform him that what had happened to me is the reason why I was not myself for the past weeks.' (Participant 5)

Participants initially found it difficult to disclose the rape to others. They feared the reaction of family and friends, and of being blamed for not protecting their partners. The participants who chose not to disclose also did so to protect their own feelings as well as those of their partners, yet did not pressurise their partners to lie to others about what had happened. It is possible that they wanted to protect their partners from exposure to further trauma.

For other participants, it was important to remain involved with their social networks in order for them and their partners to move on with their lives; however, these MIPs reported that after their friends and neighbours became aware of the rape, their partners became a topic of conversation for them. There were also those for whom, irrespective of disclosure, not one of their family or friends cared. They had nobody to talk to and so withdrew from their social networks. At the third interview session one participant expressed that he felt lonely because he was denied the opportunity to experience a sense of belonging to a family with whom he could share his painful feelings, and he blamed his family's unsupportive behaviour for reversing the progress he had made:

'My family and her family don't support me at all; they rather blame me for not looking after my girlfriend which is not good for me ... every time I think I am getting better, they accuse me for not looking after their daughter.' (Participant 6)

The MIPs reported that despite their own painful feelings, they accompanied their partners to the police station or rape centre, but had felt ignored by the professional staff. They perceived this as a disregard of the trauma that they as MIPs had suffered, resulting in a further sense of disconnect from their partners:

'Nobody at the hospital or at the police station asked me how do I feel. Nobody cares about my feelings.' (Participant 5)

MIPs who had been referred for further therapy reported either a negative initial experience with health personnel, or had refused to have additional treatment. Participant 9 said: 'Although you referred me to the day hospital after our last conversation, there were no tablets ...'

\section{Outward adjustment}

The male partners felt overwhelmed by having to cope with their own feelings and with the responses of their partners, as well as having to take over the care of their children and other domestic chores. Because the rape affected their daily routine at home, their relationship with others and their partners, they had to find other mechanisms to deal with their own feelings. Strategies such as walking, using substances to relieve their painful feelings and support from the researcher were utilised:

'When I am at work and things get too much for me, I take a walk, just so that I can forget the rape and how I am feeling because I found that if I think too much of it, it affects my work.' (Participant 9)

A participant described his experience of comforting his partner versus containing his own pain as follows:

'When I see she is worried and stressed out because she is afraid I will leave her after what happened to her. Although I am still having that feeling of killing the guys who raped her, I'm the one now who's always comforting her ... no matter what will happen in the future, I'm not going to leave her; I will always be there for her and to protect her.' (Participant 5)

One participant expressed his gratitude for the opportunity to communicate his feelings as follows:

'I think the interview helped me quite well because, like I said earlier on, I had no one to talk to. And during the interview, I had to say out things that I felt, things straight from my heart. So after the interview, I felt quite better. And right now, it seems I am coping with the situation. ... I'd like to thank you for the support that you gave me the first day ... that gave me such an encouragement and strength ... that's why I feel what I feel right now; I think it's because of that.' (Participant 3)

Participants carried the responsibility and burden of being the comforter for their partners and found it difficult to cope with their own pain, often resorting to venting their anger in a destructive manner. At the interviews conducted 24 weeks after the rape, two participants voiced that their habit of using substances to cope with their circumstances had negatively affected them over the past six months:

'The first three months after she was raped, I drink a lot, but because my girlfriend was complaining, I stopped, and since then, our communication is better because I realised that if I drink so much, and I think of the rape, I could do or say something that I didn't mean to.' (Participant 5) 


\section{Ethical considerations}

Ethical approval was obtained from the University of Cape Town's Faculty of Health Sciences Human Research Ethics Committee and the recruitment site management. The study was conducted in accordance with the principles of the Declaration of Helsinki (World Medical Association 2008). Provision was made for referral to counsellors for participants who experienced distress as a result of the interviews. All of the participants' partners had been assaulted in or near their homes, and thus participants were provided with options for the setting of the interviews, as an interview in their homes might cause distress. Participants were interviewed at a mutually agreed upon time and at a safe, comfortable venue.

\section{Trustworthiness}

Trustworthiness was incorporated by following a number of processes: credibility, dependability, confirmability and transferability. Credibility refers to the truth and believability of findings mutually established between the researcher and the participants as a true reflection of their experiences of the phenomena (Streubert \& Carpenter 2011:48). Credibility was achieved through prolonged engagement with participants and their data as well as member checking where the participants were requested to comment on the accuracy of the researcher's interpretation of the data (Guba \& Lincoln 1989).

To address dependability in the study (Polit \& Beck 2004), a detailed description of the research methods has been provided, consistency in the interview process was adhered to and pre-assumptions and possible bias were addressed through supervision and reflective journalling. Digital audio recordings and accurately written field notes facilitated recording of all the participants' verbal and non-verbal cues, such as facial expression, gestures and sobbing, to ensure better understanding of the information provided (Le Vasseur 2002). An in-depth description of the data has been provided to achieve confirmability; the primary researcher kept a reflective journal in which perceptions, emotions, thoughts, ideas and reflections on the interviews were recorded, which were discussed with the co-researchers (Streubert \& Carpenter 2011). This process facilitated disclosure of personal feelings, background, perceptions, pre-conceptions, biases, assumptions and the researcher's role in the study (Guba \& Lincoln 1989; Patton 2002).

Transferability, which enables the reader to judge applicability of the study findings to other similar contexts, has been addressed. A clear description is given of the inclusion of participants whose experiences reflected the phenomenon of the study; description of the collected data was as accurate as possible, and interpretation of the data is supported by use of the participants' own words.

\section{Discussion}

Rape is a devastating experience for the primary rape victims and their intimate partners and is an immediate crisis for both (Smith \& Kelly 2001; Rudd 2003). In this study the participants were so traumatised after learning about their partners' rape that they felt as if they themselves had also been violated. The instant they were informed of their partner's rape was a defining moment in their lives, a 'line in the sand' between their former lives and their future. The known life-world becomes an uncharted and unexplored territory, in which both partners have to re-establish their own identities and that of each other in the relationship.

The themes of being-in-the-world with their partners and being-in-the-world with others can also be viewed not only from the Ricœurean perspective but also that of Van Manen (1990), who approaches the life world in terms of the lived space and time in which relationships are fragmented, communication is tentative and threatening and intimacy needs to be re-negotiated.

People have assumptions about their lives; something that falls outside their normal terms of reference throws them into total disarray (Bower \& Sivers 1998). Trauma often violates and shakes a victim's basic assumptions about the meaningfulness of his or her physical and social worlds. This hurt and victimisation activates a negative self-image, threatening autonomy and increasing anxiety. Coping with victimisation requires the victim to come to terms with the shattered assumptions, and to make sense of the experience. This is no less important for the secondary victim as for the primary rape survivor. Finding answers and establishing meaning is different for each person. Becker (1992) refers to the phenomenological position on meaning as 'the exchange between the person and the experience.'

Despite the participants having had secure, positive relationships with their partners, the rape left them psychologically traumatised and confused about how to deal with their intimate relationships. The trauma shattered their assumptions about themselves, their relationships and the world around them, which were unchallenged prior to the crisis. Sexual assault destroys a victim's ability to maintain the important illusion of personal safety and invulnerability. The collapse of one's assumptions can undermine one's sense of control over one's own life and the circumstances around the event with which one is confronted (Taylor 1983; Thompson \& Janigian 1988). Although significant others are classified as secondary victims, this does not mean that they are in any sense less affected; the reality is only that they were not the direct recipient of the sexual assault trauma (Remer 2001; Remer \& Ferguson 1995).

Secondary or vicarious trauma is a term that refers to the trauma that significant others of the primary victim experience, and this is well recognised. This term is also used to describe the effects of sexual assault: secondary victims experience trauma symptoms similar to those of the victims and survivors (Morrison et al. 2007; Remer 2001). Secondary victims often receive recognition not because they are also traumatised but rather because of the need for their attention by the primary victim during his or her healing process. 
The actions and reactions of secondary victims can affect the recovery process of the primary victims (Duma 2006; Morrison et al. 2007; Remer 2001). Secondary victims also need professional help to recognise the symptoms and effects of trauma, to understand their own as well as their partners' healing processes, and to comprehend how the processes influence one another.

\section{Pervasiveness of guilt, anger and blame}

As a secondary victim of rape, emotions such as anger, fear, humiliation and frustration combined with feelings of violation and vulnerability are often overwhelming. Guilt, often linked to the male role of protector, leaves the secondary victim with a sense of helplessness and failure, even though there was nothing that he could have done to prevent the event. Guilt may also be an attempt to justify learning a lesson from the event and to regain some sense of power and control (O’Sullivan 2003).

These strong emotions can delay integration of the painful and horrifying event into the lives of the primary and secondary victim, and can delay constructive re-establishment of the relationship. Inability to deal with these emotions can lead to strained intimate relationships and a lack of trust and security (Duma 2006; Morrison et al. 2007; Remer 2001).

Victims try to find the answers by turning to themselves certain types of self-blame may serve as an adaptive function or defence mechanism (O'Sullivan 2003). Self-blaming as a defence mechanism enables the victim to minimise the sense of vulnerability and maximise feelings of self-control (JanoffBulman \& Wortman 1977).

\section{Post-rape intimacy}

Intimacy, particularly sexual intimacy, is for many couples an intensely private space, in which there is a sense of knowing and being known. The violation of one partner creates disequilibrium, a loss of that which is known and precious, and the fear of entering a space which is no longer safe and even sacred (Morrison et al. 2007; Connop \& Petrak 2004; Remer 2001).

\section{Secondary victims, perpetrators and the justice system}

In South Africa, with its violent and oppressive history, levels of interpersonal violence are high (Tonsing \& Lazarus 2008). There is the added lack of faith in the police and justice system (Rape Crisis 2013), and there are regular news reports of people taking the law into their own hands because of frustration with the perceived lack of efficiency of the justice system. For the secondary victims of rape this situation is no different, and some of the participants in this study expressed their desire to mete out their own form of justice in retaliation for what had been done to their partners. This may be understood as a mechanism to regain a sense of power and control over their lives.

\section{Cultural beliefs and perceptions about rape}

The intimate partners in this study were concerned about how the rapist had put their relationship at risk. Cultural background, ethnicity, community ideals and personal values might have influenced the intimate partners' experiences and the manner in which they expressed or interpreted their experiences. Cultural values strongly influence the thinking and actions of people and the way in which they respond to time, activity and relationships (Morrison-Valfre 2009). According to Smith (2005), the meaning of rape is socially constructed due to different perceptions of such situations. A fundamental distinction identified in the narratives of participants in the current study was the diverse cultural perceptions of the motive for the rape of their partners. In South Africa strong patriarchal-dominant values and norms in terms of gender roles in an intimate relationship are of importance when assessing the traumatic meaning of rape (Van den Berg \& Pretorius 1999).

Foster (2003) stressed that during assessments of persons of different cultures, professionals must be aware of the client's cultural background. This awareness will help the professional to understand the client as a whole, and will thus enhance therapeutic effectiveness. One of the cultural perceptions of intimate partners that can lead to stigmatisation is that the woman is viewed as the man's property, and that men do not share their partners with other men (Mio \& Foster 1991; Feinauer 1982; Silverman 1978). This may result in some males feeling personally wronged by the rape of their partners, and they may even display indignation from a sense of propriety that serves more to protect themselves against their own unconscious sense of vulnerability than to express a deeply held personal philosophy (Silverman 1978).

\section{Roles of professionals}

The negative responses towards professionals reflected the lack of formal, structured counselling services available for the secondary victims of rape. Participants in this study reported being ignored and neglected by the police, health and social professionals. This increased their sense of alienation, frustration and helplessness. This contrasts with the often implicit expectation that partners are a source of support for the rape victim; little cognizance is taken of the needs of the partner.

The presence or absence of professional support can either relieve or aggravate the significant other's experience of trauma (Brookings, McEvoy \& Reed 1994; Rudd 2003). Both the rape victim and her partner should receive support to allow them to continue to function as a unit (Rudd 2003). Provision of such support at an early stage of the trauma could minimise or prevent later problems and dysfunction for both partners (Davis, Lurigio \& Skogan 1997).

\section{Conclusion}

The intimate partner of the female rape victim has to live in multiple worlds, where the familiar has become strange and 
in many cases threatening, and the status of the relationship is threatened by internal and external factors.

Early interventions for intimate partners of female rape victims are required to prevent the on-going emotional trauma that partners endure after the rape. Supportive interventions could prevent or reduce the effects of chronic post-traumatic stress disorder and the silent suffering evident at personal, relationship and social levels.

\section{Acknowledgements}

This research was partially funded by an African Doctoral Dissertation Research Fellowship award offered by the African Population and Health Research Centre in partnership with the International Development Research Centre, and was also partially funded by a bursary from the Margaret McNamara Research Foundation.

The assistance of the staff of the treatment centre for sexual assault victims in Cape Town is gratefully acknowledged.

\section{Competing interests}

The authors declare that they have no financial or personal relationship(s) which may have inappropriately influenced them in writing this article.

\section{Authors' contributions}

E.v.W. (Western Cape College of Nursing) designed the study for the PhD in Nursing degree, collected the data and wrote the first draft of the manuscript. S.D. (University of Cape Town) supervised the study, commented on all drafts and approved the final draft. P.M. (University of Cape Town) cosupervised the study, commented on all drafts and finalised the manuscript for submission.

\section{References}

Ahrens, C.E. \& Campbell, R., 2000, 'Assisting rape victims as they recover from rape: The impact on friends', Journal of Interpersonal Violence15(9), 959-986. http:// dx.doi.org/10.1177/088626000015009004

Ayres, L., Kavanaugh, K. \& Knafl, K.A., 2003, 'Within-case and across-case approaches to qualitative data analysis', Qualitative Health Research13(6), 871-883. http:// dx.doi.org/10.1177/1049732303013006008

Becker, C., 1992, Living and Relating. An Introduction to Phenomenology, Thousand Oaks, Sage.

Bower, G.H. \& Sivers, H., 1998, 'Cognitive impact of traumatic events', Development and Psychopathology 10, 625-653. http://dx.doi.org/10.1017/ S0954579498001795

Brookings, J.B., McEvoy, A.W. \& Reed, M., 1994, 'Sexual assault recovery and male significant others', Families in Society 75(5), 295-299.

Campbell, R. \& Wasco, S.M., 2005, 'Understanding rape and sexual assault: 20 years of progress and future directions', Journal of Interpersonal Violence 20(1), 127. DOI: 10.1177/0886260504268604. http://dx.doi.org/10.1177/0886260504268604

Christiansen, D., Bak, R. \& Elklit, A., 2012, 'Secondary Victims of Rape', Violence and Victims 27(2), 246-262. http://dx.doi.org/10.1891/0886-6708.27.2.246

Colaizzi, P., 1978, 'Psychological research as the phenomenologist views it', in R. Valle \& M. King (eds.), Existential-Phenomenological Alternatives for Psychology, pp. 48-71, Oxford University Press, New York.

Connop, V. \& Petrak, J. 2004, 'The impact of sexual assault on heterosexual couples', Sexual \& Relationship Therapy 19(1), 29-38. http://dx.doi.org/10.1080/146819 90410001640817

Creswell, J.W., 2007, Qualitative inquiry and research design. Choosing among the five traditions, 2nd edn., Thousand Oaks, Sage Publications.
Daane, D.M., 2005, 'The ripple effects: Secondary sexual assault survivors', in F.P. Reddington \& B.W. Kreisel (eds.), Sexual assault: The victims, the perpetrators and the criminal justice system, pp. 113-131, Carolina Academic Press, Durham, NC.

Dartnall, E. \& Jewkes, R., 2013, 'Sexual violence against women: The scope of the problem', Best Practice \& Research. Clinical Obstetrics \& Gynaecology 27 (1), 3-13. http://dx.doi.org/10.1016/j.bpobgyn.2012.08.002

Davis, R.C., Lurigio, A.J. \& Skogan, L.G., 1997, Victims of Crime, 2nd edn., Sage, Thousand Oaks.

Duma, S., 2006, 'Women's journey of recovery from sexual assault trauma: A grounded theory', unpublished thesis, University of Cape Town.

Duma, S., Mekwa, J. \& Denny, L., 2007a, 'Women's journey of recovery from sexual assault trauma: A grounded theory - part 1', Curationis 30(3), 4-11.

Duma, S., Mekwa, J. \& Denny, L., 2007b, 'Women's journey of recovery from sexual assault trauma: A grounded theory - part 2', Curationis 30(4), 12-20.

Feinauer, L., 1982, 'Rape: A family crisis', American Journal of Family Therapy 10(4), 35-39. http://dx.doi.org/10.1080/01926188208250097

Foster, R., 2003, Psychological treatment of ethnic minority populations, viewed 10 March 2010, from http://www.apa.org/pi/oema/resources/brochures/ treatment-minority.pdf

Guba, E.G. \& Lincoln, Y., 1989, Fourth generation evaluation, Sage Publications, Newbury Park, California.

Haansbaek, T., 2006, 'Partner to a rape victim: How is he doing?', Journal of Sex Research 43(1), 2-37.

Jacobson, C., 2009, 'Rape linked to manhood in South Africa', Chicago Defender Online: Thursday, July '09, 2009, viewed 10 March 2010, from http://www. chicagodefender.com/article-5462-rape-linked-to-manhood-in-south-africa.html

Janoff-Bulman, R. \& Wortman, C.B., 1977, 'Attributions of blame and coping in the "real world": severe accident victims react to their lot', Journal of Personality and Social Psychology 35(5), 351-363. http://dx.doi.org/10.1037/0022-3514.35.5.351

Kim, Y., 2011, 'The pilot study in qualitative inquiry', Qualitative Social Work 10(2), 190-206. http://dx.doi.org/10.1177/1473325010362001

Lindseth, A. \& Norberg, A., 2004, 'A phenomenological hermeneutical method for researching lived experience', Scandinavian Journal of Caring Sciences 18(2), 145-153. http://dx.doi.org/10.1111/j.1471-6712.2004.00258.x

Le Vasseur, J.J., 2002, 'A phenomenological study of the art of nursing Experiencing the turn', Advanced Nursing Science 24(4), 14-26. http://dx.doi. org/10.1097/00012272-200206000-00007

Meel, B.L., 2005, 'Incidence of HIV infection at the time of incident reporting, in victims of sexual assault, between 2000 and 2004, in Transkei, Eastern Cape, South Africa', African Health Sciences 5(3), 207-212.

Miller, W.R., Williams, A.M. \& Bernstein, M.H., 1982, 'The effects of rape on marital and sexual adjustment', American Journal of Family Therapy 10(1), 51-58. http:// dx.doi.org/10.1080/01926188208250436

Mio, J.S. \& Foster, J.D., 1991, 'The effects of rape upon victims and families: Implications for a comprehensive family therapy', American Journal of Family Therapy 19(2) 147-159. http://dx.doi.org/10.1080/01926189108250844

Molloy, D., Woodfield, K. \& Bacon, J., 2002, Longitudinal qualitative research approaches in evaluation studies, Working Paper No. 7, HMSO, London.

Morrison-Valfre, M., 2009, Foundations of Mental Health Care, 4th edn., Mosby, St Louis.

Morrison, Z., Quadara, A. \& Boyd, C., 2007, 'Ripple effects' of sexual assault, Australian Institute of Family Studies, viewed 12 March 2010, from http://www.aifs.gov.au/ acssa/pubs/issue/acssa_issues7.pdf

O'Sullivan, L., 2003, 'Rape: The Journey from Victim to Survivor: A Critical Literature Survey', unpublished thesis, Masters in Psychology, Rand Afrikaans University.

Patton, M.Q., 2002, Qualitative research \& evaluation methods, 3rd edn., Sage Publications, Thousand Oaks.

Polit, D. \& Beck, C. 2004, Nursing Research: Principles and Methods, Lippincott Williams \& Wilkins, Philadelphia.

Rape Crisis, 2013, Rape in South Africa, viewed 22 July 2014, from http://rapecrisis. org.za/rape-in-south-africa/

Remer, R., 2001, 'Secondary victims of trauma: Secondary survivors', viewed 12 March 2010, from http://www.uky.edu/ rremer/secondarysur/SOCIASEC.doc

Remer, R. \& Ferguson, R.A., 1995, 'Becoming a secondary survivor of sexual assault', Journal of Counselling \& Development 73(4), 407-413. http://dx.doi. org/10.1002/j.1556-6676.1995.tb01773.x

Ricœur, P., 1976, Interpretation Theory: Discourse and the Surplus of Meaning, Texas Christian Press, Fort Worth.

Ricoeur, P.N, 1983, Time and narrative, transl. K. McLaughlin \& D. Pellauer, University of Chicago Press, Chicago.

Rudd, L., 2003, The effects of rape on the social functioning of the family, unpublished thesis Masters in Social Sciences, Rand Afrikaans University.

Schiraldi, G.R., 2000, The post-traumatic stress disorder sourcebook: A guide to healing, recovery, and growth, McGraw-Hill, Los Angeles.

Silverman, D.C., 1978, 'Sharing the crisis of rape: Counseling the mates and families of victims', American Journal of Orthopsychiatry 48(1), 166-173. http://dx.doi. org/10.1111/j.1939-0025.1978.tb01298.x

Smith, M.E., 2005, 'Female sexual assault: The impact on the male significant other', Issues in Mental Health Nursing 26(2), 149-167. http://dx.doi. org/10.1080/01612840590901617 
Smith, M.E. \& Kelly, L.M., 2001, 'The journey of recovery after a rape experience', Issues in Mental Health Nursing 22(4), 337-352. http://dx.doi. org/10.1080/01612840151136876

South African Police Service, 2012, 'Crime Statistics: April 2011 - March 2012', viewed 10 March 2010, from http://www.saps.gov.za/statistics/reports/crimestats/2012/ crime_stats.htm

Streubert, H.J. \& Carpenter, D.R., 2011, Qualitative Research in Nursing: Advancing the Humanistic Imperative, 5th edn., Wolters Kluwer, Lippincott, Williams \&Wilkins.

Taylor, S.E., 1983, 'Adjustment to threatening events: A theory of cognitive adaptation', American Psychologist 38(11), 1161-1173. http://dx.doi.org/10.1037/0003066X.38.11.1161
Thompson, S.C. \& Janigian, A.S., 1988, 'Life schemes: a framework for understanding the search for meaning', Journal of Social and Clinical Psychology 7(2/3), 260-280. http://dx.doi.org/10.1521/jscp.1988.7.2-3.260

Tonsing, S. \& Lazarus, S., 2008, Risk and protective factors to male interpersonal violence, viewed 10 March 2010, from http://www.mrc.ac.za/crime.crime.htm

Van den Berg, D. \& Pretorius, R., 1999, 'The impact of stranger rape on the significant other', Acta Criminologica 13(3), 92-104

Van Manen, M., 1990, Researching Lived Experience, State University of New York Press, London, Ontario.

World Medical Association, 2008, 'Declaration of Helsinki: Ethical Principles for Medical Research Involving Human Subjects', presented at the 59th World Medical Association General Assembly, Seoul, October 2008. 